\title{
THE METABOLISM OF CARBOHYDRATES AND OTHER COMPOUNDS BY EPIDIDYMAL-LIKE BOVINE SPERMATOZOA
}

\author{
G. N. GRAVES AND G. W. SALISBURY \\ Department of Dairy Science, University of Illinois, Urbana
}

(Received 2nd February 1966)

\begin{abstract}
Summary. The ability of bovine spermatozoa to metabolize carbohydrates and other compounds oxidatively has been studied, using spermatozoa free of the components of the seminal fluids. Only glucose, fructose, mannose and galactose of the hexoses were significantly oxidized by the spermatozoa.
\end{abstract}

An uptake of substrates from the seminal plasma and their subsequent utilization by the spermatozoa interferes with any attempt to assess the ability of ejaculated spermatozoa to oxidize other substrates. Any critical examination of substrate utilization therefore requires the use of epididymal spermatozoa. Recent investigations in our laboratory have resulted in the collection of exogenous substrate-free ejaculated sperm cells (Salisbury \& Graves, 1963) which are immobilized immediately after collection and which have the substrates of the seminal plasma partly removed by washing. These cells exhibit metabolic characteristics similar to epididymal spermatozoa and therefore have been termed 'epididymal-like cells' (ELC).

This paper reports the results of experiments designed to measure the ability of these seminal plasma-free mammalian spermatozoa to oxidize many carbohydrates, amino acids and short-chain fatty acids. The influence of $\mathrm{CO}_{2}$ on spermatozoan respiration in the presence of these substrates was investigated also.

The sperm samples (ELC) used in this study were collected as previously described (Salisbury \& Graves, 1963) and resuspended, after washing, to a concentration of 1 to $2 \times 10^{9}$ cells $/ \mathrm{ml}$ in $0.9 \% \mathrm{NaCl}$. The oxygen consumption was measured manometrically at $37^{\circ} \mathrm{C}$ in $17 \mathrm{ml}$ single side-arm flasks with air as the gas phase. The effect of $\mathrm{CO}_{2}$ on respiration under a gas phase of $20 \% \mathrm{O}_{2}$, $5 \% \mathrm{CO}_{2}$ and $75 \% \mathrm{~N}_{2}$, was studied in $17 \mathrm{ml}$ single side-arm Dixon-Keilin flasks.

Since maximum respiration of bull spermatozoa during short-time aerobic incubation occurs in saline (Bishop \& Salisbury, 1955), this was used as the suspending medium and each substrate was added at a concentration of 0.027 $\mathbf{M}(\mathrm{pH} \mathrm{7.0)}$. The cell suspension in the side-arm $(0 \cdot 2 \mathrm{ml})$ was tipped into the main body of the flask containing the $0.8 \mathrm{ml}$ of incubation medium after a 
10-min equilibration period. The endogenous respiration (in the presence of saline) and the respiration in $0.027 \mathrm{M}$ fructose $(500 \mathrm{mg} / 100 \mathrm{ml}$, the approximate level in seminal plasma) were used as controls. Aliquots, taken initially and after incubation, were analysed for fructose, lactic acid, phosphate and pyruvate as previously reported (Salisbury \& Graves, 1963).

Only the 4-hr values are given, with the respiration data given as the percentage of oxygen uptake above the endogenous controls. Analysis of variance was used to test for significant differences in the oxygen uptake data.

Of the ninety-six carbohydrates, amino acid, fatty acid and nucleic acid compounds investigated in this study, only the substrates shown in Table 1

\section{TABLE 1}

SUBSTRATES WHICH SIGNIFIGANTLY $(P<0.01)$ STIMULATED OXYGEN UPTAKE OF ELG DURING $4 \mathrm{hr}$ AT $37^{\circ} \mathrm{C}$, ALONG WITH THE $\% \mathrm{O}_{2}$ UPTAKE ABOVE THE ENDOGENOUS LEVEL, THE FINAL \% MOTILE AND THE FINAL LAGTATE PRODUCTION VALUES

\begin{tabular}{|c|c|c|c|}
\hline Substrate & $\begin{array}{c}\% \mathrm{O}_{2} \text { uptake } \\
\text { above endogenous } \\
\text { level }\end{array}$ & $\%$ motile & $\begin{array}{c}\text { Lactate } \\
\left(\mu \mathrm{g} / 10^{8}\right)\end{array}$ \\
\hline $\begin{array}{l}\text { Maltose } \\
\text { Pyruvate } \\
\text { Glycerol } \\
\text { Lactate } \\
\text { Mannose } \\
\text { Sorbitol } \\
\text { Glucose } \\
\text { Fructose } \\
\text { Acetate (K) } \\
\text { Acetate (Na) } \\
\text { Fructose-6-phosphate } \\
\text { Glyceraldehyde-3-phosphate } \\
\text { Fructose-1,6-phosphate } \\
\text { Glycerol-phosphate } \\
\text { Glucose-1-phosphate } \\
\text { Oxaloacetate } \\
\text { Glucose-6-phosphate } \\
\text { Ribose-5-phosphate } \\
\text { Galactose } \\
\text { Glyceraldehyde } \\
\text { Glycogen } \\
\text { Oxalosuccinate }\end{array}$ & $\begin{array}{r}309 \cdot 1 \\
301 \cdot 5 \\
258 \cdot 4 \\
232 \cdot 9 \\
206 \cdot 3 \\
190 \cdot 7 \\
189 \cdot 5 \\
187 \cdot 6 \\
181 \cdot 1 \\
150 \cdot 3 \\
133 \cdot 0 \\
107 \cdot 8 \\
101 \cdot 0 \\
100 \cdot 0 \\
96 \cdot 9 \\
80 \cdot 7 \\
78 \cdot 4 \\
58 \cdot 8 \\
51 \cdot 4 \\
44 \cdot 3 \\
33 \cdot 7 \\
28 \cdot 6\end{array}$ & $\begin{array}{r}45 \cdot 0 \\
12 \cdot 7 \\
16 \cdot 2 \\
15 \cdot 7 \\
17 \cdot 8 \\
14 \cdot 2 \\
22 \cdot 2 \\
22 \cdot 5 \\
7 \cdot 7 \\
10 \cdot 0 \\
8 \cdot 0 \\
1 \cdot 1 \\
0 \cdot 0 \\
13 \cdot 0 \\
17 \cdot 5 \\
13 \cdot 3 \\
7 \cdot 0 \\
2 \cdot 2 \\
21 \cdot 1 \\
0 \cdot 0 \\
0 \cdot 0 \\
11 \cdot 4\end{array}$ & $\begin{array}{r}111 \cdot 0 \\
135 \cdot 2 \\
0 \cdot 0 \\
-178 \cdot 2 \\
77 \cdot 3 \\
0 \cdot 0 \\
66 \cdot 7 \\
47 \cdot 2 \\
0 \cdot 0 \\
0 \cdot 0 \\
0 \cdot 0 \\
35 \cdot 1 \\
17 \cdot 1 \\
10 \cdot 3 \\
0 \cdot 0 \\
0 \cdot 0 \\
0 \cdot 0 \\
0 \cdot 0 \\
0 \cdot 0 \\
0 \cdot 0 \\
0 \cdot 0 \\
0 \cdot 0\end{array}$ \\
\hline
\end{tabular}

significantly $(P<0.01)$ stimulated the oxygen uptake. Five per cent $\mathrm{CO}_{2}$ in the presence of these same compounds significantly $(P<0 \cdot 01)$ stimulated cellular respiratory activity only in the presence of glucose, fructose, mannose, pyruvate, isocitrate, $\alpha$-ketoglutarate and oxaloacetate over the respiration in the absence of the $5 \% \mathrm{CO}_{2}$. Chemicals previously shown to affect cell permeability, trans-1,2-cyclopentane dicarboxylic acid (Seaman \& Houlihan, 1950) and dimethylsulphoxide (Lovelock \& Bishop, 1959), had little effect on respiration in the presence of any of the compounds.

The results show that only a few compounds can serve as sources of energy for mammalian spermatozoan motility as measured by increased respiratory 
activity and maintenance of motility. The significant increase in oxygen uptake of the spermatozoa incubated in the presence of the phosphorylated compounds, oxaloacetate, galactose, glyceraldehyde, glycogen and oxalosuccinate is undoubtedly due to the characteristic low endogenous respiration of ELC incubated in the absence of substrate (saline), in which small stimulatory effects due to metabolizable substrates are readily observed. Glycogen, for example, caused no detectable stimulation to respiration of either whole semen (Redenz, 1933) or washed spermatozoa (Mann, 1946), both of which have high endogenous respiration rates due to the uptake by the spermatozoa of substrates from the seminal plasma. Redenz (1933) using whole semen was also unable to detect a utilization of the phosphorylated compounds.

The stimulatory effect of low levels of $\mathrm{CO}_{2}$ has previously been reported to occur in spermatozoa by Salisbury \& Kinney (1957) and Jones \& Salisbury (1962).

\section{REFERENCES}

Bishop, M. W. H. \& Salisbury, G. W. (1955) Effect of dilution with saline and phosphate solutions of oxygen uptake on bull semen. Am. F. Physiol. 181, 114.

Jones, E. E. \& Salisbury, G W. (1962) Action of carbon dioxide as a reversible inhibitor of mammalian spermatozoan respiration. Fedn Proc. Fedn Am. Socs exp. Biol. 21, 86.

Lovelock, J. E. \& Bishop, M. W. H. (1959) Prevention of freezing damage to living cells by dimethyl sulphoxide. Nalure, Lond. 183, 1394.

MANN, T. (1946) Studies on the metabolism of semen. 3. Fructose as a normal constituent of seminal plasma. Site of formation and function of fructose in semen. Biochem. 7. 40, 481.

Redenz, E. (1933) Über den Spaltungsstoffwechsel der Säugetierspermatozoen in Zusammenhang mit der Beweglichkeit. Biochem. Z. 257, 234.

Salisbury, G. W. \& Graves, C. N. (1963) Substrate-free epididymal-like bovine spermatozoa. F. Reprod. Fert. 6, 351.

SAlisbury, G. W. \& KinNey, W. C., Jr. (1957) Factors influencing metabolic activity of bull spermatozoa. III. pH. F. Dairy Sci. 40, 1343.

Seaman, G. R. \& Houlihan, R. K. (1950) Trans-1,2-cyclopentanedicarboxylic acid, a succinic acid analog affecting the permeability of the cell membrane. Archs Biochem. 26, 436. 